\title{
Tourism Destination Products Management - Case Studies of Phu Quoc Island Kien Giang Province, Vietnam by 2020
}

\author{
Nguyen Cong Hoan \\ Faculty of Tourism, University of Finance and Marketing, Vietnam
}

Copyright $(2015$ by authors, all rights reserved. Authors agree that this article remains permanently open access under the terms of the Creative Commons Attribution License 4.0 International License

\begin{abstract}
Phu Quoc is an island district of Kien Giang province in the south of VietNam. Phu Quoc island district is far from Rach Gia city about $120 \mathrm{~km}$ and Ha Tien town about $45 \mathrm{~km}$. Phu Quoc district has got 22 large and small islands, with an area of $593.05 \mathrm{~km} 2$, and have 99 hills from the North to South of island, 13 beautiful beaches, the forest accounts for $63.74 \%$ of the area of Phu Quoc island. It is considered to have the potential to develop unique tourism resources in both the human and natural resources. It is endowed with four sides sea surrounded with hills, rivers, streams, waterfalls and mountains with primeval forests, wetlands, beautiful beaches. The district of Phu Quoc island has got the hundreds of islets bobbing at sea windy. Visitors travel to the tourism homestay in the village of pearl farming, fish sauce village, planting pepper village, Sim's wine producers, ....attending the MICE, events, festival; visiting Phu Quoc's prion, Cau Temples; Phu Quoc Natural Park forest, Phu Quoc waterfall, Tranh stream, ecotourism island; buying some souvenirs; eating and driking foods and beverages; and staying in one to five stars resorts and hotels. Destination management is the co-ordinated management of all the elements that make up a destination (attractions, amenities, access, marketing and pricing). Therefore, developing tourism Destination management of Phu Quoc district in a sustainable way means restructuring the economy, create jobs and contribute to poverty reduction and improved livelihoods families. It would have become specific destination's tourist management at present and future.
\end{abstract}

Keywords Tourism Products, Tourism Destination, Tourism Destination Management, Phu Quoc's Tourism Destination Management

\section{An Overview of the Phu Quoc Island}

Natural geographic conditions: Phu Quoc district is the largest island of Vietnam, located in the Gulf of Thailand, Kien Giang Province. Phu Quoc island district is far from Rach Gia city about $120 \mathrm{~km}$ and Ha Tien town about $45 \mathrm{~km}$. Phu Quoc district has got 22 large and small islands, with an area of $593.05 \mathrm{~km}^{2}$, long island of $50 \mathrm{~km}$, and have 99 hills from the North to South of island, 13 beautiful beaches, the forest accounts for $63.74 \%$ of the area of Phu Quoc island.[25]

Administrative offices: Phu Quoc district has got 2 towns as Duong Dong and An Thoi towns and 8 communes located in the many Islets as Duong To Commune, Cua Can, Ganh Dau, Cua Duong, Bai Thom, Hon Thom, Ham Ninh, Tho Chau communes. [25]

Population, ethnics and religions: there were approximately 103,000 people, including Kinh ethnic is about $96.76 \%$; Chinese is about $1.92 \%$; Khmer ethnic is about $1,23 \%$ and other ethnic is about $0.09 \%$. The Phu Quoc district has 5 main religion is Buddhism; God of Jesus; Cao Dai; Hoa Hao; and other religions.[5]

Economy: Phu Quoc Island has potentially tremendous economic development, has a significant advantage in transport linkages maritime, aeronautical countries in the region and around the world. The field of trade and services, construction, transport (including sea, air) has developed rapidly. People's living standards are raised. Many major economic indicators have met and exceeded the plan and some growth indicators higher than the previous year; Phu Quoc's tourist has been increasing demand for the development of tourist services.

Tourisms: The domestic and international tourists travel to increasing the Phu Quoc island. Visitors go to the Phu Quoc island for Leisures, MICE, discover new beach and entertainment in watersea with diverse tourism resources and rich with specific tourist products, and visit to Phu Quoc Peper villages, Phu Quoc fish sauce villages, Sim wine village, Phu Quoc dog farm, Ham Ninh fishing village, pearl farming; to swim and to visit sightseeing Phu Quoc beach with the sand running along the coast; to visit Phu Quoc's prison; some other monuments [12]. Therefore, domestic and 
international tourists travel to Phu Quoc Island for many different purposes, such as visiting relatives, public service, sightseeing, festivals, tourism on the island homestay much less the different seasons, ... and other forms of tourism should be based on the actual situation of each growth visitors Phu Quoc island has different tourism products. Data forecasting domestic and international tourists to the Phu Quoc island as follows:

According to CBRE's report (2014), the number of domestic tourists to Phu Quoc increased continuously in recent years, averaging 24\% in seven years. In 2013, Phu Quoc welcomed 622,479 visitors, of which domestic tourists accounting for $80 \%$ and increased up doubled compared with 2012. In 2014, tourist's Turnovers reached VND 2,228 billion, up $84 \%$ compared with 2013. [5]

Means of transportations: Tourists can be go to Phu Quoc Island by airplane at the Phu Quoc International airport, the capacity can reach up to 2.7 million people a year by 2020 and 7 million in 2030 compared with 760 thousand people a year by 2013 to at the present; and other means going to Phu Quoc by boats or by Express Superdong I and II, or go fishing boats of the fishermen [10]. Visitors travel from $\mathrm{Ha}$ Tien town or Rach Gia city to Duong Dong town or An Thoi town in Phu Quoc Island about 2-4 hours.

\section{Tourism Resources of Phu Quoc Island}

Natural tourism resources: Phu Quoc island has many natural resources include elements of geology, topography, geomorphology, climate, hydrography, ecosystems and natural landscapes which can be used for tourism purposes [1]. Phu Quoc Island has got many islets, hills, rivers, streams, waterfalls and the sea. It has the long white fine sands of beaches, forests, flora and natural landscape has made these attractive tourist destinations for the local and foreign tourists.[22].

To exploit the natural tourism resources in the field of tourism products become the wonderful and attractive destinations at present and future. Phu Quoc Island is not far from the mainland, it is about $45 \mathrm{~km}$ from Ha Tien town and $120 \mathrm{~km}$ from Rach Gia city of Kien Giang province [12]. Phu Quoc Island has got the natural advantages of the landscapes, rivers, streams, waterfalls, a lot of small islets, and phytosanitary systems and forest ecosystems. Visitors can visit and swim some places such as Phu Quoc National Park forest, Khem beach, red land beach (Dat Do beach), Dam Bay beach, Sao beach, Co Chin Mountain, Radar Mountain, and Thom rock islet, Then rock islet, Kim Qui rock islet, Tranh streams, Phu Quoc waterfalls, Da Ban waterfalls and fishing villages, Vong beach, Vem canal ... the tourism product attractive destination for guests love nature [9].

Humanity tourism resources: Phu Quoc island include the cultural traditions of the sea over the years reserved months and become products of various special cultures. Every year, it has organized various types of culture, performance of arts, festivals, cultural factors; folk literature; historical, and architectural relics; creative works by human beings; and other tangible and intangible cultural heritage which can be used for tourism purposes [8]. Coming to Phu Quoc Island, the visitors can admire and enjoy the Whale's festival of the fishermen in fishing village; traditional festivals of ethnic groups; the religious festival, the festival commemorates national heroes, ancestor festival; traditional villages of people fishing villages, craft fishsauce, wine myrtle, pepper village... and many cultural heritage objects like houses, pagodas, temples, Phu Quoc's prison, Ham Ninh fishing village, and the other valuable monuments of the island. The entertainment activities are at the sea, the resorts, hotels and catering sea [13]. Those products have been put into the destination tourism product of Phu Quoc Island.

\section{Theoretical Considerations}

Destination: A geographical area (city, region, village, that a particular guest (or segment of guests) choose for its leisure objective). Therefore the destination is the competitive unit in the incoming tourism market. The destination has to be run as a strategic business unit; A destination is a geographical area consisting of all the services and infrastructure necessary for the stay of a specific tourist or tourism segment.[24]; Destinations are the competitive units of incoming tourism. Destinations are therefore an important part of a tourism product. [24]

Tourist Destination: Destination contains a number of basic elements which attract the visitor to the destination and which satisfy their needs on arrival. These basic elements can be broken down into attractions (the must see) or "must dos" and the other remaining elements [2]; A tourist destination is basically a travel destination that attracts large numbers of travellers, or tourists. Travelers may visit these destinations to see historical sites, natural wonders, or buildings. Some tourist attractions also have activities, such as rides or games, or unusual novelties. Souvenirs are often sold at these destinations, and many of these areas rely on the income generated by the travellers that visit. [28].

Tourism products: Tourism product lines and product items, like manufactured products, pass through life stages that progress from birth to death. The tourism product is launched, grows to maturity, levels off and then gradually declines. If identified in time, refurblishing and re-introducing the product under another guise, or with a fresh injection of publicity may evert the decline.[24]. Tourism product is a series of interrelated services, namely services produced from various companies (economically), community services (social aspect) and natural service. According Suswantoro on substantially the understanding of tourism products "is obtained and the overall services felt or enjoyed by tourists since he left his residence to the tourist destination of his choice and to return home where she originally departed" [29];

Or Tourism product is the inclusion of a whole tourism package to meet the clients' expectations. These would include accommodation, tourism, meals, entertainment, transport among others. It can be divided into a local product 
to encourage the citizens to participate or international products for revenue collection; A destination's tourism product mix comprises all those product lines and product items that are made available to tourists the region [7].

According to VietNam's Tourism Law, Tourism product means a combination of necessary services provided in order to meet the needs of tourists during a trip. [17].

Destination management: Destination management is the coordination and integration of all the elements of the destination mix in a particular geographic area based upon a defined tourism strategy and plan. The destination mix elements are the attractions and events, facilities (Hotels, restaurants, ...), transportation, infrastructure, and hospitality resources (Mill and Morrison, 2012). In addition, destination management encompasses the image - making branding, and marketing and communications of all threat the place has to offer to tourists.

Destination management is the co-ordinated management of all the elements that make up a destination (Attractions, amenities, access, marketing and pricing). Destination management takes a strategies approach to link - up these sometimes very separate entities for the better management of the destination joined up management can help to avoid duplication of effort with regards to promotion, visitor services, training business support and identify any management gaps that are not being addressed. [24].

\section{The types of tourist destination products of Phu Quoc Island}

1. Blue tourism and sport: Travel Route for leisure tourism products from the Phu Quoc islands and beach, sea, sun, sand and coasts [15]...;

2. Ecotourism (or rural tourism): Eco-tourism, study visits varied ecosystems of the area such as: the forest, plains and rivers, streams and staying at home/communities tourist. [11].

3. Cultural tourism: visit monuments, learn culture history, Religious and rituals tourist..;

4. The festivals and events tourist products..;

5. The business tourism: Business and professional, MICE tourist products;

6. The cuisines: enjoying the local cuisine specialties;

7. Sustainable tourism: visit the Phu Quoc National Park forest, communities, visitors, infrastructure, enterprise, administration...;

8. Disaster: tour for Tourist products from the local disasters such as Storm sea, fishing boat sea.

\section{Methodology}

Due to our main objective is to analyze kinds of destination's tourism products in Mekong river delta provinces, in a first step this research is designed to use quantitative method by using self - administered questionnaire with closed the Departments of Culture, Sport and Tourism of Kien Giang province [22]. The researchers use the list of the Decision for Report of the Project of plan for tourism development on Phu Quoc Island, Kien Giang province period 2006 - 2020, [22]. The researchers also obtained name the General Statistics Office of Vietnam, Ha Noi (2013) [5], Method of analysis and synthesis, and method of Compare and contrast of destination attraction products which attract the visitor to the destination and which satisfy their needs on arrival. These basic elements can be to plan tourism marketing strategy forward 2020 [18]; and Approval of the project "Development of sea travel, training and coastal area Vietnam 2020" [19]; and report of Tourism product development special of Mekong delta river region [20].

The methodology will be applied to Kien Giang Province and Phu Quoc district by myself going to direct research. However, the research is both a teaching tourism and a tour guild should have many years of experience researching and collecting information on destinations, products, tour route to the Mekong delta provinces, specially Phu Quoc Island. This way we will be able to choose the tourism products in the destination attraction in Phu Quoc Island, Kien Giang provinces of Vietnam that most visitors need it.

\section{Results}

The orientation development of the route tours and tourism destination products management is a key element of the tourism destination products management in Phu Quoc island, Kien Giang provinces, Viet Nam to become the sustainable destination's tourism products in the future, which is to develop, expand and improve those experiences that appeal to the selected destination target Phu Quoc Island, VietNam.

In order to promote strength in each area, building specialty tourism products on the basis of tourism resources such as: natural, ecological, cultural, facilitates the development of associated destination's tourism products, taking advantage of the facilities of the local, territorial partition Phu Quoc Island tourist is divided into many tour areas. In devising route tours the tourism destination products management portfolios in the Phu Quoc island (Phu Quoc district), Kien Giang provinces [22] the following process may be followed:

\section{Destination's products from local tangible and intangible culture}

- Festival: Nguyen Trung Truc Festival, Whale festival in the freshing fish villages in Phu Quoc Island, Kien Giang province.

- Traditional village: Pepper planning village, net fishing, sauce - fishing village, pearling farm, Sim wine making processes villages and net weaving villages... in Phu Quoc Island, Kien Giang province..[12]

- Visiting historical sites: Phu Quoc's Prion, Pogodas, Cau Temples, Cau's Temple night market and ect..

2. Destination products from Sea, sand, sun, stream, forest: 
attending to the racing sailing, boats, fishing squid, shrimp, crab, fish...swim in the sea; pearl farming village on the sea.

3. Destination products from Foods and Beverages: Development of food service to introduce domestic and foreign tourists about local cuisine will be unique tourism products of the brand and create local tourism as Sim fruit wine, fruit juice, and others.

4. Destination products from Business: Attending MICE, leisure, hospitality, study, seminas, international Conferences, Festival and event in Phu Quoc Islands as: Vietnam's Miss contest, Vietnam's beauty contests, water sports contest in the sea...[13].

5. Destination products from Sustainable tourism: Visiting the Ecotourism (or rural tourism) in the primary forest, tour gardens such as: the forest, plains; Visiting the eco tourism community in Phu Quoc National Park forest, tourism research ...

- Visiting the Ecotourism (or rural tourism) in the primary forest, tour gardens such as: the forest, plains and sea, eco - tourism community, tourism research in Phu Quoc Natural park forest, Tranh stream, Da Ban waterfalls,...[12].

6. Destination products from inter-regional and inter-national: Receiving and travelling the international tourist 5 star cruiseships to Visit some landscapes, entertainment on the sea in Phu Quoc, traditional village...

7. Destination's tourism products from Sport and recreation

- Visiting the boat racing, canoeing on the sea;

- Attending to fishing fish in the sea, fishing squid, shrimp, crab, fish in the nightsea with freshmen.

8. Destination products from living community:

- Travel experience life the freshmen, combine people stay at homes/communities in traditional villages, living and doing with people, travel community learning.

\section{Conclusions and Implications}

The development and management of tourism destination products from tourism resources plays an important role in the economic - culture - society development of the Phu Quoc island, Kien Giang province, Vietnam. Developing destination products and tourism destination products management in a sustainable way means restructuring the economy, create jobs and contribute to poverty reduction and improved livelihoods families. Although abundant tourism resources and diverse natural landscape with beach, coast systems, streams, islets create unique tourism product of this places, along with tourism resources of human to the cultural and historical monuments, the cultural intangible and cultural intangible values created panorama of development tourism products here. Therefore, the Phu Quoc Island has tourism destination products management in tourism development plan of destinations, and need to building tour routes as followed:
1. Cultural tour routes:

- Tour routes of historic sites - Revolution: Visiting Phu Quoc Prison, Cau temples, pogados, historical revolutionary.

- Tour routes of visiting traditional villages: visiting and sightseeing the traditional fishing villages, pepper villages, sauce fish villages, Phu Quoc dogs, farming pearl villages,..

- Tour routes of homestay: living and working at one day in homestay's fishermen; pearling farm; making sauce-fish; planting peppers; fishing squid, or shrimp, or crab, fish at a nightsea with freshmen.

- Tour routes of Events or MICE: Attending MICE, leisures, hospitality, study, seminas, international Conferences, Festival and events in Phu Quoc Islands as: Vietnam's Miss contest, Vietnam's beauty contests, water sports contest in the sea...

2. Eco-tourism tour routes:

- Tour routes of Eco-tourism: visiting the Phu Quoc National park Forest, picturesque streams, Phu Quoc's waterfalls, The $\mathrm{Da}$ ban waterfall (or table rock stream), ... research natural ecosystems in the North Island and the mainland including coastal waters shore (Cau Trang, Hon Mot, Rach Tram); waters off of South An Thoi Island Cluster.

- Tour routes of entertainment and leisures: swimming and sightseeing the Leisure and entertainment resorts and hotels at the coasts with 3S: Sea, Sand and Sun; Phu Quoc's racing dogs; driving Canoes, boats in the Duong Dong, Ba Keo, Bai Truong, Dat Do, Khem, Bai Sao, Vong, Rach Vem, Ganh Dau, Long Beach, Vung Bau beach, Cua Can beaches in the coasts of Phu Quoc island.

3. Phu Quoc's Cuisines tour routes

- Tour routes of Cuisines: Discovering and enjoying the Phu Quoc's Culinary and shopping as seafood dishes from the sea, Sim liquor wine.... shopping souvenirs made of shells, snails, pearls in Phu Quoc Market or Phu Quoc nightmarket.

4. Cruiseships route:

- Tour routes transiting 5 stars of cruiseship: International tourists are transiting to sightseeing and shopping in Phu Quoc island 1 day.

- Cruise tour route: route Rach Gia to Phu Quoc, Ha Tien - Phu Quoc, Ha Long - Phu Quoc, Phu Quoc - Tho Chu and vice versa...

Destination management tends to be most easily organised on public sector boundaries at the district, subregional, provincial or state level because the public sector is the deliverer of much of this infrastructure. Destination management could also be organised around a distinct attraction, such as a river, valley, resort, sports, leisures, landsacpes, or a stretch of coastline or a unique natural or 
cultural attraction in Phu Quoc island.

\section{REFERENCES}

[1] Le Huy Ba, 2006, Eco-Tourism, Science and Technology Publishing House, Hanoi

[2] Cho. B. H 2000 "Destination", in J. Jajari (Ed), Encyclopaedia of Tourism, Routuedge, London and New York

[3] Douglas C. Frechtling, (2001), Forecasting Tourism Demand: Methods and Strategies, Butterworth Hetnemann,

[4] General Department of Tourism, 2010, Non Nuoc Vietnam, publisher of social labor, Hanoi

[5] The General Statistics Office of Vietnam 2014, Ha Noi

[6] Jordi Datzira Masip, Director of DDS, Tourism product development: A way to creative value the case of La Vall Lord, Barcelona, April 2006.

[7] Heath, E.T.and Hall, G., (1992), Marketing tourism Destinations, John Wiley and sons, USA

[8] Nguyen Cong Hoan, (2015), Tour guide practices, University of Finance - Marketing, HCMC, 2014

[9] Nguyen Cong Hoan, (2014), Vietnam Travel Routes, University of Finance - Marketing, HCMC, 2014

[10] Nguyen Cong Hoan, (2014), Orientation development of tourism destination products in the Mekong delta river provinces, Vietnam by 2030, 7th World Conference for Graduate Research in Tourism Hospitality and Leisure, Proceeding book, ISBN:978605-4940-25-7, by Anatolia, Istanbul, Turkey, 2014.

[11] Nguyen Cong Hoan, (2014), Orientation and Exploitation Strategies of natural resources used Mekong Delta regional for council planning for sustainable tourism development to 2020, Publisher National University of Ho Chi Minh City, HCMC.

[12] Nguyen Cong Hoan, (2014), Village planning for Phu Quoc Island become a tourism destination products to 2020 and for looking forward to 2030, Publisher National University of Ho Chi Minh City, HCMC.

[13] Nguyen Cong Hoan, (2013), Forecasting demand and tourism development strategy of mekong delta provinces - vietnam become tourist attraction destination looking forward to 2020, Silpakorn 70th Anniversary International Conference 2013,
Bangkok Thailand, (1st - 3rd december 2013 at Hotel Novotel Bangkok on Siam Square, Thailand).

[14] Institute of Tourism Development Research, Report of tourism development projects in the Mekong Delta in 2020, HN, $1 / 2010$

[15] Institute for Tourism Development Research (ITDR), (2010), The Report of the Project of Mekong Delta tourism development to 2020, HN.

[16] J. M. Ali-Knight, (2011,) The role of niche tourism products in destination development, PhD by Published Works

[17] Law on Tourism, No 44/2005/QH11 of June 14, 2005, on Tourism, VietNam.

[18] Ministry of Culture, Sports and Tourism, Tourism development strategies Vietnam for 2020, looking forward to 2030, Hanoi, 2013

[19] Ministry of Culture, Sport and Tourism, No: 2782/QĐ-BVHTTDL, Approval of the project "Development of sea travel, training and coastal area Vietnam 2020", 2013

[20] Ministry of Culture, Sport and Tourism, Report of Tourism product development special of Mekong delta river region, 2015

[21] Prime Minister, No: 321/QD-TTg, date 1802 2013, Decision approving the National Action Plan tourism for the period 2013-2020, Hanoi 2013

[22] Primer Minister, No: 01/2007/QĐ-TTG, date 8th January, 2007, Decision for Report of the Project of plan for tourism development on Phu Quoc Island, Kien Giang province period 2006 - 2020, Ha Noi, 2007.

[23] Resolution No. 54/NQ-HDND, dated 07.11.2013 passed in the tourism development plan in Tien Giang province in 2020 and vision to 2030

[24] World Tourism Organization (2007), A Practical Guide to tourism destination management, World Tourism Organization calle Capitan Haya, 42 208020, Madrid, spain first 2007

[25] http://www.Kiengiangvn.vn

[26] www.tourismphuquocisland.com/vi/

[27] www.phuquocexplorer.com

[28] http://www.wisegeek.com/what-is-a-tourist-destination.htm)

[29] http://lokatourconsultant.blogspot.com/2013/04/tourism-prod uct-definition.html 